\title{
Visual Fragments and the Politics of Place: \\ Feminist Advocacy in Czech Public Culture
}

\author{
Kristina Horn Sheeler
}

\begin{abstract}
This essay analyzes how Forum 50\%'s visual “argumentative fragments” (Delicath \& DeLuca, 2003) respond to and make visible the gendered norms of Czech political culture and advocate for women's increased levels of participation, representation, and legitimacy. Forum $50 \%$ 's visual rhetoric provides a compelling case to assess the argumentative resources of image events, the politics of place, and the role of humor for feminist work in the public sphere and on the public screen. Through an examination of Forum 50\%'s visual strategies, this essay demonstrates the importance of orchestrating a visible public image that commands political agency and dismantles gendered stereotypes while taking advantage of the rhetorical resources within a specific cultural context and place. Forum 50\%'s campaign expands our understanding of gender and social protest, demonstrates the extent to which women can work toward political equality in a post-communist environment, and explores the potential for visual argument to spark social change.
\end{abstract}

Key words: Czech Republic, Forum 50\%, visual rhetoric, image events, public screen, humor, strategic juxtaposition

On August 10, 2010, three women in drag stood outside the Czech parliament building in Prague holding a sign that read "We Want into Government.” Czech media flocked to the story, reporting that the women had been denied admission to the parliamentary floor. The guard who refused their request asserted that parliament is not a "masquerade” and such "antics" are not appropriate in the hallowed halls of government. This visual protest was not the first orchestrated by Forum 50\%, an NGO in the Czech Republic, and it is representative of a much larger campaign launched by the organization in April of 2010 to encourage the public —-through both traditional and innovative means_- to rethink the role of women in public political life. The potential for visual forms of protest to spark public participation in (and shape understanding of) key social and political issues is a central concern of this essay. I argue that Forum 50\%'s visual rhetoric illustrates the powerful argumentative resources created through image events, the 
politics of place as a rhetorical construct, and the role of humor in advancing feminist activist work in the public sphere and on the public screen.

Forum 50\%'s protest demonstrated the organization's disappointment that the newlyformed cabinet does not include qualified women in high-ranking political positions. In a televised interview, Prime Minister Peter Nečas laughed dismissively at the public spectacle (Události, komentáře, 2010). Yet the developing media narrative conveyed a compelling and serious story: qualified women were being denied entrance to parliamentary leadership. Czech TV 24 devoted ten minutes of its 60-minute news and commentary program to the issue on the day of the protest. Outlets such as Mediafax.cz, ParlamentníListy.cz, and iDNES.cz picked up the story and its accompanying visuals, noting that the women in "painted beards” were not allowed on the parliamentary floor (Čermáková, 2010; Procházková, 2010; Women with fake beards, 2010). These visual fragments worked in concert to capture the growing sense of public dissatisfaction with and illegitimacy of the government as represented by the men in parliamentary leadership. Moreover, the physical place itself—parliament—and images barring women's entry to it underscored not only the arbitrary nature of political power as gendered masculine but also the importance of place as rhetorically constructed and contested in particular cultural contexts.

This study contributes to the ongoing conversation about the role and importance of visual forms in public argument. Following the "visual turn” in argument studies ${ }^{1}$, scholars have assessed the ways visual imagery constitutes our understanding of important social, political, and identity issues (e.g., LaWare, 1998; DeLuca \& Peeples, 2002; Delicath \& DeLuca, 2003; Finnegan, 2003; Pezzullo, 2003; Palczewski, 2005; Morris III \& Sloop, 2006; Hariman \& Lucaites, 2007; Popp, 2010). This essay examines visual argumentative fragments employed by 
Forum 50\% to reconstitute understanding of women’s representation in politics. My analysis addresses both the visual and humorous elements of the argumentative fragments that became an important resource for Forum 50\% in its efforts to challenge notions of women's participation in Czech political culture. I also consider how grassroots feminist activism in the public square extends the organization's humorous visual approach, advancing our disciplinary understanding of the public sphere outside a U.S. context.

The “We Want into Government” protest and accompanying media coverage are an example of an image event. John W. Delicath and Kevin Michael DeLuca (2003) write that “image events are a postmodern form of argument that employs acts of protest to deliver images as argumentative fragments that serve as inventional resources for public deliberation and which shift the responsibility for argument construction to audiences” (p. 317). Capitalizing on both a face-to-face and hypermediated environment to disseminate its activist message using spectacular and conventional means, Forum 50\% takes advantage of the power of image events to provide the "unstated propositions, indirect and incomplete claims” (Delicath \& DeLuca, 2003, p. 322) that become fodder for public argument construction as individual citizens are invited to participate in the messaging. In this essay, I analyze the "We Want into Government" image event as one part of a larger campaign that relies on the power of mimicry and strategic juxtaposition to critique the accepted invisibility of women in the political sphere. These image events outside a sacred building and other significant public places occured at a time when the Czech government juggled internal problems between parties, growing economic woes, and lack of confidence from the public. The strategically planned "antics” in front of the parliament building juxtapose the solemnity of the place with the demands of the women, prompting a very legitimate question: Why are women barred from decision-making at a time when the country 
faces very serious problems that include all members of the public, both women and men? Another question, more central to the purposes of this essay, is: To what extent can women achieve social change in a post-communist country in which existing forms of women’s political participation are seen as connected to the prior regime?

Achieving social change in Czech public culture necessitates careful negotiation of the resources of argument. The campaign rhetoric of Forum 50\% engages humor strategically to interrogate cultural stereotypes of both masculinity and femininity in ways that reveal the invisibility of women in Czech politics. The NGO's visual rhetoric questions not only the low number of women in government, but also the legitimacy of any government barring half the population from the parliamentary floor. In considering Forum 50\%'s political discourse from April to October $2010^{2}$, I explore how visual “argumentative fragments” operate as resources for "generative argument. ... to increase the number of participants in the public sphere, expand opportunities for public advocacy, and broaden the horizon of possible ideas in social controversies” (Delicath \& DeLuca, 2003, p. 317, 324). Face-to-face and mediated tactics are central to the success of this campaign, as is attention to the politics of place. Whereas Kevin Michael DeLuca argues that image events have a mediated audience and protesters who engage in image events must use an intermediary to get their message out, Forum 50\% does not relinquish this control. In fact, this aspect of face-to-face interaction and specifically planned mediated events broaden DeLuca's theory to include the orchestration of the visual spectacle that is so important to feminist advocacy. Because Czech feminist activists are so easily dismissed as inappropriate, out of bounds, or connected to the prior regime, it is particularly important for them to maintain message control in this political culture. 
My analysis of Forum 50\%'s visual rhetoric is informed, first, by Kevin Michael DeLuca and Jennifer Peeples' discussion of image events on the public screen. Realizing the importance of visual rhetorical forms in shaping public argument in unconventional ways, DeLuca (1999) describes “image events” as staged forms of protest advanced by social movements that demand public televisual dissemination. DeLuca and Peeples (2002) argue that image events must be taken seriously for their rhetorical power as “critique through spectacle” (p. 134). DeLuca (1999) develops his framework through an analysis of environmental rhetoric; he and Peeples (2002) extend on this work in an analysis of WTO protests in Seattle that posits the public screen as an alternative to the public sphere, highlighting characteristics such as "dissemination, images, hypermediacy, [and] spectacular publicity” (p. 145).

A second study important for understanding the power of Forum 50\%’s visual argumentative forms is Anne Teresa Demo’s analysis of the Guerrilla Girls rhetorical style. Demo (2000) employs Kenneth Burke’s perspective by incongruity to assess the activist feminist rhetoric of the Guerrilla Girls and its potential for social critique, seeking "to correct the inadequacies of the present social order” (p. 135). Demo argues that the group’s visual strategy confronted institutionalized sexism, making the viewer ready for another perspective. Demo’s as well as DeLuca and Peeples’ analyses illustrate what DeLuca (1999) argues is visual rhetoric's ability to "[reconstitute] the identity of the dominant culture by challenging and transforming mainstream society’s key discourses and ideographs” (p. 16). Because both studies hinge on the use of activist tactics to transform cultural discourses, they are particularly relevant to considering the public communication work of Forum 50\%, a task that also challenges our primarily U.S.-focused understanding of gender and protest by considering visual politics in another context. ${ }^{3}$ 
Marta Kolářová (2009) considers protest forms in the Czech Republic, focusing specifically on the Prague protests of 2000. The "Pink Block” protesters wore pink dresses and skirts to signify "love and peace” (p. 100). While noting short-term success, she argues that the use of these tactics was ultimately deemed weak and ineffective. The "adoption of tactics was influenced by the already known and familiar methods that did not threaten established gender roles. .. . Pink Block was not understood as a chosen strategy and temporary performance, but as a further feminization and objectification of women” (p. 101). As an alternative, she encourages protest groups to develop strategies “for gaining legitimacy and public recognition, and ... generate creative and innovative features for sustaining the attention of the mass media” such as the “"clown army' - a non-violent, creative form of protest mixing masculinity and femininity” from the alter-globalization movement (p. 104). Forum 50\%'s campaign certainly fits that description as well. The image events featuring women in men's clothing in front of Parliament assert their right to get into government, depicting political women as active, assertive agents while simultaneously challenging the construction of gender in Czech political culture. Before turning to an analysis of Forum 50\%'s visual rhetoric, this essay details the context in which the organization mounted its activities and considers prior research on women's political identity and representation in post-communist countries in order to illustrate the barriers Forum $50 \%$ faced.

\section{Women’s Political Representation Post-Communism}

Press coverage indicates that the problem of low numbers of women in Czech politics has festered for quite some time. On December 23, 2008, Jůn Dominik reports “the Czech Republic’s D- grade for women in politics” on Radio Praha. The story features interviews with prominent leaders of women’s advocacy groups recounting the poor showing of women in 
political roles in this otherwise "progressive” society. Calling it a "dire situation,” the commentator reports that women make up only $17.3 \%$ of directly elected Senators and $15.5 \%$ of proportionally elected members of the lower house of parliament. The percentage of women who serve in the European Parliament is similar. According to a September 23, 2009 report in the Czech Daily Monitor, “The Czech Republic ended almost at the very bottom of the EU countries' ladder as regards female participation in the European Parliament after the June European elections. Only four Czech women [18\%] became members of the new European Parliament.”

Less than a year later, however, women gained more seats than ever before in the lower house of the Czech parliament in the May 2010 elections, increasing their numbers from 31 to 44 (out of 200 seats). In the October senate elections, numbers increased from 14 to 15 (of 81 seats). These numbers are compelling when considered alongside existing research on the political system. Women's level of political representation is nearly twice as high in countries that elect their members of parliament using a proportional system as compared to countries with a majority/plurality system such as the United States in which candidates are directly elected (Rule, 1994; Norris, 2000; Amy 2002; Matland, 2002; Reynolds, Reilly, \& Ellis 2005). Conventional wisdom indicates that sexist attitudes are to blame for the low numbers of women in government; yet according to a 2009 public opinion poll conducted in the Czech Republic, a majority of respondents support women’s activity in public life and specifically encourage women to become active in politics (Center for Public Opinion Research, 2009). The same poll demonstrates a slight majority of respondents support changing the voting mechanism to ensure balanced representation of women and men on party lists. 
While the public may be supportive, the scant research that exists on women's political representation in post-communist countries reveals three interrelated challenges to increased levels of political participation of women in a Czech Republic still showing traces of the legacies of communist control. Each of these obstacles has to do with deeply held cultural assumptions related to gender, necessitating an ideological shift that only a focus on the communicative norms implicit in political leadership can begin to address. The primary obstacles are: perceptions of women parliamentarians as tokens, traditional assumptions about gender, and cultural associations with concepts such as feminism and equality.

Prior to 1989, 25\% of the seats in the governments of former Czech, Soviet, and Yugoslav states were considered reserved “women’s seats,” by order of the regime. Galligan and Clavero (2008) argue:

The token nature of women’s parliamentary presence not only served to mask important gender inequalities in the political sphere but also created an image of the female politician as a compliant and willing supporter of the regime. The negative image of the manipulated female politician had important consequences for the overall level of women’s political representation when parliamentary quotas were removed after 1989. (p. 152)

Ideologically, female political activity commanded (and still commands) a strong resonance with the dictates of the prior regime rather than any level of legitimacy, voice, or agency on the part of women in contemporary political culture. In the first democratic election after 1989, women’s representation in the Czech Republic fell to single digits and was among the lowest in Central and Eastern Europe, demonstrating the challenge faced by any organization seeking to increase women's political participation and advance women's political equality. Cultural attitudes in the 
Czech Republic indicate a marked resistance to orchestrated notions of equality barely a generation removed from the end of the communist era. Thus, any campaign that seeks to increase women's levels of representation must negotiate the cultural weight of ideographs such as quota or equality. ${ }^{4}$

The prevalence of traditional assumptions about gender functions as a related barrier that keeps patriarchal arrangements in place. Scholars of Czech culture see conventional gender roles persisting in the public-private sphere negotiations of family life. In this cultural context, the private sphere has traditionally been the domain of women, whose primary responsibility, in addition to being a worker-citizen, is to care for home and family. Men, historically, are thought to hold a legitimate grip on the public sphere as primary breadwinners. Galligan and Clavero (2008) find that “[t]hese private-public arrangements fostered a set of traditional attitudes toward gender that were later reinforced by the resurgence of a conservative discourse after 1989 that idealized women’s traditional roles in the family and the community” (p. 152). Argent (2008) describes the Czech Republic as a society "where men are seen to rule politics and women the family” (p. 100). As Ferber and Raabe (2003) explain, Czech women often view "gender differences as embedded in nature and as resulting directly from the biological differences between men and women” (p. 423). In addition, they note that this perspective contributes to Czech women who "are apparently not eager to run for public office or to compete with men in that arena” (p. 423). The authors address the importance of the dual role of Czech women, explaining, “Czech women take pride in being both homemakers and breadwinners, and strongly identify with both these roles” (p. 423). Raabe (1998) contends that although "Czech women and men continue to endorse such gender differentiation" it is also the case that "Czech women generally have not viewed themselves as victims of gender inequality or oppression, but rather as 
strong and capable” (p. 57, 59). In order to advance an ideological shift in the communicative norms of Czech political culture, campaign messaging must link proud, "strong and capable” Czech women with political agency.

Any effort in post-communist countries to mobilize around women's issues or women's equality has a difficult task ahead not only because of strong notions of traditional gender roles, but also because of perceptions associated with terms such as feminism. Wolchik (1994) finds that because the regime itself emphasized and implemented women’s equality "from the top down” rather than as something “chosen by women themselves meant that it was very much associated with the communist system. Once that system ended, many rejected the goal of gender equality along with other aspects of the old system” (p. 101). Cerwonka (2008) explains that a broad range of opinions exists “on feminism’s usefulness in Central and Eastern European societies . . . from sympathetic to the markedly hostile equation of feminism with communist totalitarianism” (p. 809). Political advancement for women must not be justified as a feminist project, but a grassroots effort chosen by women themselves as political agents. For this reason, any campaign that engages women and men directly in a grassroots effort will have an increased potential for social change.

Women’s organizations that have developed since 1989 do not claim a feminist political identity, but their agenda may suggest otherwise. Wolchik (1994) explains that “many [women’s organizations] do allow women to identify their own interests, and some have engaged in political actions designed to influence public opinion and political leaders” (p. 105). In particular, “Women and women’s groups in both the Czech Lands and Slovakia have been active in raising issues of interest to women. However, these groups are generally small, poor in 
resources and unable to fight the prevailing skepticism about or hostility toward anything that might be labeled feminism” (p. 105).

Given the prevalence of the perception of women parliamentarians as tokens, traditional assumptions about gender, and ideological associations of feminism and equality with a communist agenda, it is no wonder that Forum 50\% premises its activities on breaking down stereotypes and emphasizing the strength and agency of women in public political roles. According to a personal interview with Miša Appeltova (a Deputy Director of Forum 50\%) on March 30, 2010, the organization believes that gender stereotypes are a major barrier to seeing more women in public life. In addition, Forum 50\% understands the challenges inherent in advancing an argument that relies on “equality” or “women’s issues” or “quotas,” given the ways that such terms resonate with the prior regime. As a result, any campaign must first confound culturally ingrained gender stereotypes and advance an understanding of women's competence in public life that is not also associated with "special” or "reserved" seats, leading to a fundamental remaking of the culture’s “dominant discourses and ideographs,” as DeLuca (1999) notes (also DeLuca \& Peoples, 2002, p. 134). Forum 50\% accomplishes this purpose through the use of humor and a series of image events from April through October 2010.

\section{Forum 50\%, Humor, and Visual Spectacle}

Visibility is an important consideration for the rhetorical potency of any feminist activist project; as Anderson and Sheeler (2005) argue, “public power accrues not only to those who 'look,' but also to those who are seen” (p. 63). Orchestrating one’s public spectacle by controlling the message is key. The campaign launched by Forum 50\% in early April 2010 urges the public to "give your preferential votes to women" and makes visible gender and its 
construction in the political realm. Capitalizing on "critique through spectacle" (DeLuca, 1999, p. 22; DeLuca \& Peeples, 2002, p. 134), Forum 50\%'s campaign calls attention to the ways in which the political is constructed as masculine and uncovers the absurdity of limiting women's participation in public life.

The primary rhetorical problem the NGO addresses relates to visibility: how to get the public to see the sexism inherent in the political status quo. Once the public confronts this problem, they will be more likely to confirm the strength and capability of women in public political roles and to exercise their preferential voting power. Forum 50\% took advantage of both face-to-face and image-dominated, spectacular political culture in its visual rhetorical response. Expanding DeLuca's notion of the hypermediacy of the public screen, Forum $50 \%$ orchestrated its visual spectacle on posters, t-shirts, cartoons, bumper stickers, flyers, television spots, blog posts, video contests, YouTube, Facebook, and through personal appearances around the Czech Republic. Thus, the application of DeLuca’s work to Forum 50\%’s campaign emphasizes the value of enlisting the grassroots public to aid in the dissemination of the message. In other words, a multitude of argumentative fragments become resources for engaging the public in new lines of argument. Whereas image events rely primarily on mediated audiences, here face-to-face interlocutors become part of the performance. The dominant image on which this spectacle is built is the chicken.

\section{Reclaiming the Chick}

The visual rhetoric executed by Forum 50\% relies on the character of a "laughing chick" 5 to garner humor and poke fun at cultural stereotypes of both masculinity and femininity to reveal the invisibility of women in Czech politics. According to Kakalik, the cartoonist who developed Kuře (Chicken), the cartoon strip originally commanded modest readership in the Czech 
Republic. Yet the visibility of the main character, a young chicken depicted as a "laughing chick," exploded because of its centrality to Forum 50\%'s campaign. The cartoonist acknowledges that Kuře in Czech resonates with the slang term for woman in English: chick, or “an inexperienced girl” (personal communication, July 2011). Anderson and Sheeler (2005) recount a history of referring to women using animal metaphors that both dehumanize them and emphasize their relationship to men (p. 29). In this case, however, the audacity of the "chick" as she calls out the invisibility of women in parliament disrupts a constructed and gendered subjectivity that maintains women's lack of authority in the political realm. The “chick” laughs at the audience and is an image of power appropriated by Forum $50 \%$. The image asks the audience to reconcile the debilitating label, “chick,” with the chick’s laughter at the absurdity of the absence of women's voice from political culture, and, most importantly, to recognize the audience's apparent complicity in the process. The “chick” makes visible the issue of equal representation for women and men in the political sphere, calls public attention to gender stereotypes, and functions as a resource to pave the way for an alternative perspective.

Forum 50\%’s campaign reclaims the “chick” in order to subvert its power of subordination. This tactic is similar to the power that Anne Teresa Demo finds in the visual rhetoric of the Guerrilla Girls. In her analysis, Demo (2000) argues that the group employed Burke's “perspective by incongruity” through mimicry, re-visioning of history, and strategic juxtaposition in order to demonstrate the power of visual rhetoric as a source of feminist resistance. Demo’s discussion of mimicry is particularly useful to understanding the power of the visual spectacle created by Forum 50\%’s laughing chick. Mimicry involves claiming “an exaggerated version of traditional femininity” in order to subvert its power of subordination and recast it as affirming (p. 141). Just as the Guerrilla Girls reclaimed the term girl, Forum 50\% has 
reclaimed the chick. With its petite beak, bright yellow feathers, and exaggerated belly laugh, the "laughing chick,” like the Guerrilla Girls in Demo’s analysis, “fractures associations between the feminine, passivity, and subordination that maintain patriarchy” (p. 142). The laughing chick taps into the belief held by Czech women that they are "strong and capable” (Raabe, 1998, p. 59) and aligns that belief with political agency. As a result, the laughing chick functions as a powerful argumentative fragment, visually refuting the discourses of the dominant culture regarding gender and political visibility.

[insert Figure 1]

You got the balls...to vote...for a woman??!

\section{GIVE YOUR PREFERENTIAL VOTES TO WOMEN}

The “chick” gained visibility in cartoons like the one depicted above. ${ }^{6}$ These cartoons were displayed on bumper stickers and t-shirts and distributed at concerts, movies, and other public places as well as via press releases, press conferences, blog posts, and social media sites such as Facebook. By asking “you got the balls . . . to vote for . . . a woman?,” the “chick” relies on both feminine and masculine stereotypes in advancing her unruly humor. Essentially, the “chick” asks, “are you man enough” to vote for a woman? By demanding that the audience look at and laugh with the “chick,” the base humor begins to undermine the power of cultural stereotypes equating masculinity ("balls”) with public political culture and femininity (the “chick”) with private domestic culture. Not only does the "laughing chick” compel male viewers “to symbolically identify against themselves” as does the Guerrilla Girls visual rhetoric (Demo, 2000, p. 143), but the sexual humor and the laughter of the chick also playfully make visible and complicate the binary opposition constructed between women and public political power. 
Three additional cartoons form the nexus of Forum 50\%'s “give your preferential votes to women” visual arsenal: ${ }^{7}$

I’m running for office!!! . . . but I'm afraid . . . that I don’t have the cock??!

GIVE YOUR PREFERENTIAL VOTES TO WOMEN!!!

Politically I am dead . . . does it mean that . . I am a WOMAN??!

GIVE YOUR PREFERENTIAL VOTES TO WOMEN!!!

I vote for a woman!!! . . . and perhaps also for . . . a change!!!

\section{GIVE YOUR PREFERENTIAL VOTES TO WOMEN!!!}

Each cartoon displays the "chick" in three panels like the example above. In the third panel of each, the "chick's” expression changes to visually emphasize the absurdity of the claim, employing the tactic Demo (2000) calls “strategic juxtaposition.” Relying on Allen and Faigley (1995, p. 159), Demo defines strategic juxtaposition as “"bring[ing] together in a state of tension the discourses of two or more status groups'” (p. 147). In each of these cartoons, an exaggerated form of femininity in the petite-beaked, yellow-feathered chick is juxtaposed strategically with a claim advancing the strength, capability, and political agency of Czech women. The chick in "But I'm afraid" covers her eyes in the third panel to mimic literal fear at the absence of "the cock.” The tension between submissive femininity and political virility/masculinity claims presence in the imagery, compelling the viewing public to reconcile the exaggeration. It works in a fashion similar to "You got the balls," commanding that the public view, literally, the failure to see represented by the blinded chick. In the process, the viewing audience confronts its own inability to see the crisis of women's underrepresentation in parliament and is urged, through the final line in all caps, to act: "give your preferential votes to women.” 
In "Politically I am dead,” the third panel portrays a “crazy chick,” with red eyes glaring. This image calls upon the stereotype often invoked to discredit public women or women who have transgressed in some way: emotional excess. This cartoon responds to the propensity of some traditional Czechs to view gender differences as connected to biology in ways that reinforce the public-private sphere divide (Ferber \& Raabe, 2003; Galligan \& Clavero, 2008) and forces the Czech observer to confront the logic of the juxtaposition directly and see the irony in the claim. As a result, a newly generated narrative thread invites the voting public to view women through a more politically active, less stereotypical lens.

"I vote for a woman" may be subtler in tone, which serves to emphasize the strategic juxtaposition. The reluctant words in each panel and the active image of the chick play up the contradiction and the resulting irony. The language "and perhaps also" mimics "feminine speech patterns” that signal reluctance, passivity, or uncertainty (Kramer, 1974; Kramarae, 1981; Lakoff, 1975; McMillan, Clifton, McGrath \& Gale, 1977). However, the visual displays a chick who throws down her fist in the final panel to draw attention to the "change" desired. The imagery of the fist-wielding chick is anything but hesitant or uncertain and underscores the force of the demand to see women and to take them seriously as political agents. To put the demand into practice, the viewing audience must "give [their] preferential votes to women."

The laughing chick as argumentative fragment becomes a form of feminist resistance that unmasks gender's construction in the political sphere and the public's acceptance of the status quo. The entire “chick” campaign goes beyond the spectacular publicity DeLuca and Peeples (2002) note, exciting public visibility through direct, often base, language, imagery, and humor. The use of humor is compelling, adding an important component to Demo’s (2000) assessment of mimicry and strategic juxtaposition. In this case, it is not only the visual argumentative 
fragment that offers the critique, as the humorous juxtaposition invites the audience to participate with laughter as it generates a different perspective. Through a belly laugh, shaking fist, or bawdy language, the "chick” asserts her right to be seen and heard as she engages the audience to rethink the relationship among women, men, and public political life, and then act accordingly. The next step is to disseminate the visual argumentative fragments more broadly through a series of image events that engage both face-to-face and mediated display to demonstrate the importance and vitality of the public sphere.

Grassroots Appeal in the Public Sphere and the Politics of Place

In the two months leading up to the May 2010 lower house election, Forum 50\% took its message to the public sphere to attract attention to and generate media coverage of the issue of preferential votes for women and the under-representation of women in parliament. In their analysis of the WTO protests in Seattle, DeLuca and Peeples (2002) discuss the power of image events, arguing that they are marked by “dissemination” rather than dialogue, and focus on how "the image event...highlights the public screen as an alternative venue for participatory politics and public opinion formation” (p. 145). Perhaps it is the perceived absence of the public sphere that motivates DeLuca and Peeples’ discussion. They recall critics such as Nancy Fraser, Kendall Phillips, and Michael Schudson, for example, who suggest the public sphere has never really existed or that it is an "indispensable" ideal or dream shaping the way we think of democratic practice. The concept of the public screen as a "supplement" to the public sphere, then, frees us to envision "the places of politics and the possibilities of citizenship in our present moment" (DeLuca and Peeples, 2002, p. 131). However, Forum 50\%'s tactics rely on both the public sphere and the public screen to disseminate its visual fragments and, in the process, reconstitute the vitality of the public sphere in our televisual age. This difference is important, especially in a 
post-communist political culture that still recalls state-run media and is skeptical of any topdown approach — a place where grassroots appeal is absolutely essential to advance social change (Wolchick 1994; Cerwonka 2008).

Traveling from town to town in the Czech Republic, gathering support for women and preferential votes, the “chick” demands visibility and challenges cultural assumptions and stereotypes of the appropriateness of women in public political life. Anyone might be found wearing the “chick” costume on these journeys, from Jana Smiggels Karková, Director of Forum $50 \%$, to another woman, man, or child associated with the NGO. Men or children wearing the costume demonstrate that this is not simply a women's issue, but is about the legitimacy of decision-making powers that affect the lives of everyone. The "chick" is always accompanied by several members of the NGO, one of whom carries a poster-size cartoon displayed with the red and blue logo of Forum 50\% to make clear the organizational origins of the argumentative fragments. The cartoon is visually prominent on t-shirts and handed to passers-by to enlist them in the discourse of the campaign.

Place plays an important role in the discourse of Forum 50\%’s campaign and in conceptualizing the deliberative possibilities of the public sphere. During the chicken's travels, she engages the public not just in any public space, but in culturally important and meaningful places. The central town square is one such place where the public sphere can be seen in practice. Although DeLuca and Peeples (2002) acknowledge that the public screen has not replaced the public square, finding it a fruitful framework for analysis in "retheorizing the places of the political” (p. 147), public, face-to-face attention in the town square may be the more important avenue through which to disseminate the political in the Czech Republic. This claim is not meant to suggest nostalgia for a simpler time, but instead point out the advantages of relying 
on the rhetorical resources of a particular cultural moment and place. It is important to note that Czech culture revolves around face-to-face interactions in the public square. Weekend activities are held in the town square. People meet, gather, sit, chat, and interact in those spaces. Government buildings, local shops, restaurants, coffee shops, food carts, flower venders, entertainment stages, and town events bring families, business owners, tourists, performers, journalists, camera crews, and government officials to the town square. Fleming (1998) argues that "a place with large numbers of different people in frequent contact, a place where people identify with one another even as they reveal their differences, a place with safe public spaces for gathering and decision-making —-may provide a better context for the development and flourishing of argument” (p. 162). In the case of the Czech Republic, the town square is the most appropriate place in which to stage an image event, garner attention, talk, and disseminate messages. This fact explains why the chicken most often took her visual message to this public place.

The importance of using familiar places to advance a new argument alternative is significant in Forum 50\%’s grassroots dissemination. Danielle Endres and Samantha SendaCook (2011) argue that "places, imbued with meaning and consequences, are rhetorical performances” (p. 260). The familiarity of the public square in Czech political culture aided Forum 50\%’s advancement of visual claims about women’s political agency and opened possibilities for a new perspective to emerge. Meshing the unconventional with the familiar is not a new tactic, but doing so helps make visible the rhetorical potential of the public sphere in our visual age. Forum 50\%'s attention to the place of argument not only creates opportunities for grassroots public engagement with the issues, but it also means that journalists are at the ready in 
this space. Activity in the public square is then re-mediated on the public screen. The chicken engages the public directly, which is then rebroadcast on the nightly news.

These grassroots efforts in the public sphere and on the public screen appear to have paid off. The May election returned a record number of women to the Czech lower house and Forum 50\% expected women to fill leadership positions in the new government. However, in August 2010, the new prime minister's decision to ignore qualified women in the formation of his cabinet was a disappointment to many and indicated much work remains to improve gender equity in government. This decision means that the Czech Republic and Hungary are the only two countries in the EU with no women in the cabinet. In the wake of this election, Forum 50\% continued to demand public attention to the underrepresentation of women in politics. One image event through which the campaign continued to drive home its message occurred on August 10, 2010. Women dressed in men's clothing and held a sign with a simple demand: "We Want into Government.” The women stood in protest outside the Czech parliament building in Prague, a building familiar to anyone in the country (much like the the United States Capitol for a U.S. public).

The visual appeal of the protest at the Czech parliament building illustrates the rhetoric of place that is often so important to social protest. Endres and Senda-Cook (2011) argue that protest events "use particular places to challenge the dominant meanings of such places and temporarily enact alternate meanings” (p. 268). Once again Kenneth Burke’s “perspective by incongruity” (Demo, 2000) is at work through strategic juxtaposition. The masculine markers of beards, mustaches, ties, and masculine attire are an odd juxtaposition to the demand "We want into government!” Men already hold a majority of seats in the Czech parliament and all the seats in the new cabinet. Yet when worn by women claiming a masculine identity and standing in 
front of Parliament, tension is aroused as the women question the legitimacy of "the very institutions that canonize such images” (Demo, 2000, p. 149). Following Demo’s argument, just as the Guerrilla Girls ask, “Do women have to be nude to get into the Met. Museum?”, Forum 50\% poses a similar question: “Do women have to dress in men’s clothing to get into Parliament?” The juxtaposition brings to the fore not only the constructed absence of women from the seats of political leadership, but also the rhetorical power enshrined in such a place.

The importance of place in Forum 50\%’s campaign contributes to our disciplinary understanding of the public sphere and feminist advocacy. DeLuca and Peeples (2002) discuss the notion of "embodied voices" that is privileged in discussions of the public sphere. Problematically, as some critics suggest, such a perspective "idealizes the face-to-face encounter and privileges such speech as authentic” (DeLuca and Peeples, p. 130). Yet, the embodied feminist voice in the public square is crucial to Forum 50\%'s campaign. Too often, women’s voices are muted, co-opted, silenced, or made invisible when others speak for or about them. Certainly this is the case in Peggy Phelan's (1993) assessment of Operation Rescue; the pregnant woman is made invisible even while representations of the unborn fetus become marked and visible. This leads her to question the efficacy of "visibility politics as a way to secure political power for the under-represented” (p. 170). Yet Phelan’s argument is based on an understanding of performance and/or visibility politics as nonreproductive (p. 148). In other words, performance is not something that can be reproduced; "the gazing spectator must try to take everything in. Without a copy, live performance plunges into visibility . . . and disappears into memory” (p. 148). Forum 50\%’s case, however, illustrates more than visibility politics; it illustrates the power of the embodied feminist voice in the public sphere. When women orchestrate their spectacle, maintain message control, and, importantly, enlist others in their 
grassroots efforts in the public square, it is more difficult to dismiss their claims as inappropriate or illegitimate. Furthermore, those spectators who participate in the message at important public places are not mere spectators, but become part of the discourse of the public sphere, embodied voices that aid in the further dissemination of the message.

Tactics of the public screen employed in the public square advance our understanding of the rhetoricity and vitality of the public sphere as a place of political advocacy. DeLuca and Peeples (2002) review numerous critical accounts of the decline of the public sphere privileging Habermas's normative ideal that "holds static notions of the public arena, appropriate political activity, and democratic citizenship, thus ignoring current social and technological conditions” (p. 131). However, the visual argumentative fragments deployed by Forum 50\% that rely on the character of the laughing chick interacting in the public square are anything but static. Forum $50 \%$ capitalizes on the rhetorical potential of the public sphere and assessment of the NGO's campaign is an answer to DeLuca and Peeples' call to attend to "what is happening and what is possible under current conditions” (p. 134). Forum 50\% demonstrates rhetorical ingenuity as the organization embraces one of the requirements of the public screen noted by DeLuca and Peeples: "the need to communicate in the discourse of images” (p. 136). The organization does so in the public square and on the public screen. For example, the cartoons and the central character of the chick provide the argumentative resources, to which face-to-face interactions with the chicken and associated image events add rhetorical force. Staged events at culturally important places provide a non-traditional avenue to gaining voice and capturing public participation and media attention. In the case of Forum 50\%, public participation is not only televised, but disseminated via newspapers, radio, and the public square. Forum 50\% prepared a programming series highlighting the lack of women in government that aired on Czech 
television $^{8}$, received media attention in response to their staged events, and compelled the media to participate productively in the dialogue, which further advanced the momentum of the discussion. Being aware of the rhetorical resources provided in this particular cultural context may have promoted more discussion of the image events and associated political messages.

\section{Disciplining the Feminine?}

On the heels of the "We Want into Government" image event, the October municipal and Senate campaigns garnered much more media coverage than any other image event during the six months under study. The chicken took to the streets again with a vengeance and a schedule publicized via press releases and announced in each city with a spot on Radio Blaník. Most of the planned events were held in major city squares. Television news, photos, and headlines drew attention to the issue of women's representation in the local and Senate elections, through such coverage as the display on tn.cz online in October 2010 featuring the "Do you have the balls to elect a woman?” headline and cartoon.

One image event is of particular note. During the October election, Forum 50\% staged a public protest at the polling place where the Czech president and first lady would cast their votes. The NGO could not have asked for better participation by the media. ${ }^{9}$ George Hronik reporting for ParlamentníListy.cz includes a photo and writes on October 15, 2010 that the president voted for the party of his choice, but the first lady received a leaflet promoting the "more weaker sex" and "split [her] votes between multiple candidates.” The story then suggests that Mrs. Klaus “perhaps [was] influenced by activists," in response to the chance meeting with the chicken and the protestors. In the images, the first lady appears amused by the cartoons and campaign paraphernalia, as does the chicken, adding a layer of legitimacy to the visual fragment of the laughing chick. The photo captures a first lady who will not be disciplined, even with a man in a 
suit looking on with a serious expression on his face. The visual and media report underscore the political agency of a first lady who votes according to her own opinions, and resonate with the cultural belief of the strength and agency of Czech women-further complicating the dominant discourse that places women outside public political culture.

This instance is a compelling example of the ways that images provide argumentative resources for thinking of ourselves as citizens and of our roles in political culture. Other scholars have noted the import of visual culture in the construction of citizenship and national identity (Hariman and Lucaites, 2007; Popp, 2010). The appearance of the first lady in the visual fragment becomes much larger than a chance meeting on Election Day with a member of the voting public. First ladies are the markers of "womanhood," signifying the role, place, and voice of women in a particular culture. Anderson (2004) argues that the role of the American first lady is such a site through which we publicly negotiate expectations for female identity. As Anderson notes, “[d]iscourses by and about first ladies function culturally to shape notions of femininity and so both foster and constrain women's agency” (p. 18). At a time when the Czech Republic witnessed had increased levels of women's political participation just a few months earlier, bolstered by public opinion that supports women's active participation in public political life (Center for Public Opinion Research, 2009), the visual fragment portrayed by a laughing first lady held a compelling power to generate a new argument. Visually, the Czech first lady is at ease with the chicken, despite the disciplinary gaze of the male onlooker. Her laugh links her with the "laughing chick" found in the cartoons in her hands. She exercises her independent agency in her voting choice. While not an elected official in her own right, she embodies the “strong and capable” image that Czech women hold of themselves (Raabe, 1998, p. 59) and 
compels viewers to expand their cultural understanding of women to include political decision making as well.

The fact that Forum 50\%’s image events were staged at politically-loaded places such as the parliament building and the voting location of the president and first lady contributed to the disruption of traditional discourses historically associated with those places. "The confluence of physical structures, bodies, and symbols in particular locations construct the meaning and consequences of a place. Social movements tactically (re)construct the place in which protests occur in line with their challenges to the status quo” (Endres \& Senda-Cook, 2011, p. 276). The visual argumentative fragments engage not only the tradition with which the places are infused, but also significant players in the public political culture that may not have been engaged by more traditional forms of argumentation. The media participation and dissemination put these interlocutors together on the stage of public opinion, creating the opportunity to challenge those traditional discourses defining what it means to be a member of parliament or a woman in Czech political culture. The result is the additional narrative capturing the irony of barring the women “in painted beards" from parliament and the agency of a first lady who finds amusement in the campaign and votes with her own mind. Her image, broadly disseminated, became a resource for rethinking the role of women as citizens in Czech political culture as well. The construction of gender became a central component of the discourse in those rhetorical places, underscoring that the communicative norms of political culture, rather than biology, drive traditional notions of who has a legitimate public political voice in a newly constituted public sphere. 
One significant contribution of this essay is an understanding of the relationship between place as it has been constructed rhetorically and public visual argument forms. Significant public places, impregnated with historical and cultural meaning, are central to Forum 50\%’s argument. On one hand, the organization violated the sanctity of the place of the parliament building in its image event “We Want into Government.” In doing so, the mediated discourse allowed for a shift to include discussion of the absurdity of women's constructed absence from this place. In addition, centralized public squares, hallmarks of community and vitality in this particular cultural context, provide opportunities for direct engagement rather than mere spectatorship or observation of televisual argument. More importantly, activity in the public square is then remediated on the public screen, demonstrating the rhetorical potential of the public sphere in this particular context. Future studies of the potent force of visual argument forms may wish to examine its connection to traditional political and public places to secure engagement with unconventional claims.

The image events orchestrated by Forum 50\% from April through October 2010 show a critical engagement with the cultural barriers that words like equality, quota, or feminism create for any campaign advancing women’s political agency in the Czech Republic. Just as Catherine H. Palczewski (2005) identifies intersections between ideographs and visual rhetoric, this essay argues that the image events and corresponding media and face-to-face coverage of Forum 50\%'s activist work confound the cultural assumptions on which the ideographic understandings of equality, quota, and feminism lie. Visually, through mimicry and strategic juxtaposition, viewers are presented with alternative notions of Czech women’s political agency in public life. Alternative ways of seeing compel Czech citizens to confront culturally held beliefs about women's and men’s roles. By means of cartoons and the corresponding “Chicken campaign,” the 
NGO demands attention on its own terms, orchestrating its political spectacle, maintaining control of the message and its dissemination, and as a result, accruing public political power. The “We Want Into Government” image event as well as the image of the laughing first lady, undeterred by the stern male in the background, challenge dominant discourses regarding the prohibition of women in politically-charged places and the role of women as independent agents. In these ways, the campaign begins to "[reconstitute] the identity of the dominant culture by challenging and transforming mainstream society’s key discourses and ideographs,” which DeLuca (1999) identifies as an important characteristic of image events (p. 16).

An important extension of DeLuca's argument to address women's political agency is the issue of message control. The protestors in DeLuca's studies had to rely on an intermediary to disseminate the message; image events, for DeLuca, do not often have a non-mediated audience. However, Forum 50\% never relinquished that sort of control of its message. Not only did it engage in grassroots efforts to enlist the public in message dissemination, but the NGO also actively created its message for the media by orchestrating its spectacle for radio, television, the Internet, public display, and dissemination. This difference is key for feminist organizing. Too often, and especially in post-communist contexts, efforts toward women's advocacy are considered out of bounds, easily relegated to the realm of taboo, or connected to the prior regime. As a result, maintaining message control and enlisting grassroots support are significant strengths of campaigns such as Forum 50\%.

Another important contribution of this essay is the ongoing scholarly discussion on the value of paradox and strategic juxtaposition for women's political activism. In particular, Forum 50\% enacted visual paradox, creating a space that opened up opportunity for discussion, debate, and dissemination of alternative visual cues. The visual paradox created the possibility for 
alternative perspectives to be made visible, calling into question the very cultural understandings about women and public political roles that limit half the population from parliamentary leadership. Based upon this case, the potential for social change of visual argument forms in feminist activist work is great, not only in the Czech Republic, but around the globe.

Contributions to the literature on women's political agency are gleaned from this study as well. First, it is important to harness the resources of visibility and spectacle in order to be heard. Image events, in particular, offer a rich resource to do so. However, that visibility is not simply an ability to be seen and heard. If the visual fragment is to have longer-term implications, it cannot be relegated to or coopted by anything that might be deemed taboo, traditional or takenfor-granted. The strength of Forum 50\%’s campaign is that it takes gendered stereotypes (“crazy eyes," covered eyes, feminine features of the "chick”) and juxtaposes them strategically with physical and verbal demands to underscore the constructed nature of women's invisibility in the political sphere. These fragments function as argumentative resources to make visible women's lack of political agency, poke fun at it, or take it to the absurd extreme, challenging the public to see political women in new credible ways. This newfound sight contributes to a changing discursive terrain challenging long-held communicative norms of Czech political culture.

Forum 50\% takes advantage of public opinion open to women filling political roles, as 2009 public opinion poll results demonstrate, and does not emphasize calls for equality or quotas to achieve political agency. This aspect of the campaign is important in a post-communist culture where grassroots organizing is a much more compelling demonstration of feminist agency. But the same outcome may not be the case in a country that is not as willing to consider women for public political offices. Further, even though Forum 50\%'s overall strategy is clearly based on exposing the absurdity of the norms of a political culture that constructs masculinity as the norm 
and femininity as Other, that argument may resonate just as strongly with the anti-incumbent sentiment fueling much of the political turn-over in 2010. Regardless, one of the strengths of the campaign is its awareness of cultural constraints and opportunities for social change. The Chicken Campaign evolves in the midst of larger questions about the government's legitimacy; the "We Want into Government” protest is a specific image event that captures the public mood questioning the appropriateness of any government barring half the population from the sacred places in which decisions are made. And as the media reports point out, the women were literally barred from the parliamentary floor, confronting the viewing and reading public with the imposed invisibility of women in the government, opening the possibility of alternative perspectives.

The 2010 election season in the Czech Republic makes for a compelling case study in the use of visibility and spectacle as political argumentative fragments. Forum 50\% takes advantage of the rhetorical and cultural resources at its disposal, strategic juxtaposition, hypermediated imagery, and a culture attuned to face-to-face interactions in the town square in order to begin the process of re-making political culture's communicative norms. This case demonstrates the inventional power of image events, the politics of place, and the possibilities of grassroots feminist advocacy, especially when humor is a foundational component of the activist message. Future studies of our mediated political culture may do well to look also at the opportunities face-to-face discourse in the public square provide for mediated discourse on the public screen as both demonstrate the rhetorical strength and vitality of the public sphere. 


\section{References}

Allen, J.M. \& Faigley, L. (1995). Discursive strategies for social change: An alternative rhetoric for argument. Rhetoric Review, 14, 142-172. doi:10.1080/07350199509389057.

Amy, D.J. (2002). Real choices / New voices. New York, NY: Columbia University Press.

Anderson, K.V. (2004). The first lady as a site of “American Womanhood”. In M.M. Wertheimer (Ed.), Inventing a voice: The rhetoric of American first ladies of the twentieth century, (17-30). New York: Roman and Littlefield Publishing.

Anderson, K. (2011, July 16). Re: Girls gone mad: The wild-eyed lunacy of Bachmann, Pelosi, Clinton ... etc. [Web log message]. BagNews. Retrieved from http://www.bagnewsnotes.com.

Anderson, K.V. \& Sheeler, K.H. (2005). Governing codes: Gender, metaphor, and political identity. Lanham, MD: Lexington Books.

Argent, A. (2008, April). Hatching feminisms: Czech feminist aspirations in the 1990s. Gender \& History, 20, 86-104. doi:10.1111/j.1468-0424.2007.00510.x.

Bari. (2010, May 28). Politicians appeal to women to use their preference votes. Eurozpravy.cz. Retrieved from http://domaci.eurozpravy.cz.

Center for Public Opinion Research. (2009, June). Status of women in the eyes of the Czech Republic. Retrieved from http://aa.ecn.cz/img_upload/666f72756d35302d6669313030313139/Zaverecna_zprava_ VVM.pdf.

Čermáková, D. (2010, August 10). Women with painted mustache could not [enter] the house. Mediafax.cz. Retrieved from Mediafax.cz. 
Cerwonka, A. (2008). Traveling feminist thought: Difference and transculturation in Central and Eastern European feminism. Signs: Journal of Women in Culture \& Society, 33, 809-832.

Czech News Agency. (2009, September 23). Retrieved from http://praguemonitor.com/2009/09/23/womens-group-calls-quotas-women-politics.

Delicath, J.W., \& DeLuca, K.M. (2003). Image events, the public sphere, and argumentative practice: The case of radical environmental groups. Argumentation, 17, 315-333.

DeLuca, K.M. (1999). Image politics: The new rhetoric of environmental activism. New York: The Guildford Press.

DeLuca, K.M., \& Peeples, J. (2002). From public sphere to public screen: Democracy, activism, and the "Violence" of Seattle. Critical Studies in Media Communication, 19, 125-151.

Demo, A.T. (2000). The guerrilla girls' comic politics of subversion. Women's Studies in Communication, 23, 133-156. doi:10.1080/07491409.2000.10162566.

Dominik, J. (2008, December 23). The Czech Republic’s D- grade for women in politics [Radio broadcast]. Radio Praha. Retrieved from http://www.radio.cz/en/article/111646.

Endres, D. \& Senda-Cook, S. (2011). Location matters: The rhetoric of place in protest. Quarterly Journal of Speech, 97, 257-282.

Ferber, M.A. \& Raabe, P.H. (2003). Women in the Czech Republic: Feminism, Czech style. International Journal of Politics, Culture \& Society, 16, 407-430.

Finnegan, C.A. (2003). Picturing poverty: Print culture and FSA photography. Smithsonian Institution Scholarly Press.

Fleming, D. (1998). The space of argumentation: Urban design, civic discourse, and the dream of the good city. Argumentation, 12, 147-166. doi:10.1023/A:1007735612744. 
Galligan, Y. \& Clavero, S. (2008, April). Prospects for women’s legislative representation in postsocialist Europe: The views of female politicians. Gender \& Society, 22, 149-171. doi:10.1177/0891243207312268.

Hariman, R. \& Lucaites, J.L. (2007) No caption needed: Iconic photographs, public culture, and liberal democracy. Chicago: University of Chicago Press.

Hroník, G. (2010, October 15). The members of the initiative surprised the polling place of the presidential couple. ParlamentníListy.cz. Retrieved from http://www.parlamentnilisty.cz.

Kolářová, M. (2009). Fairies and fighters: Gendered tactics in the alter-globalization movement in Prague (2000) and Genoa (2001). Feminist Review, 92, 91-107. doi:10.1057/fr.2009.8.

Kramer, C. (1974). Women’s speech: Separate but unequal? Quarterly Journal of Speech, 60, 14-24. doi:10.1080/00335637409383203.

Kramarae, C. (1981). Women and men speaking: Frameworks for analysis. Rowley, MA: Newbury House.

Lakoff, R. (1975). Language and women's place. New York: Harper \& Row.

LaWare, M.R. (1998). Encountering visions of Aztlan: Arguments for ethnic pride, community activism, and cultural revitalization in Chicano murals. Argumentation and Advocacy, 34, 140-153.

Matland, R.E. (2002). Enhancing women’s political participation: Legislative recruitment and electoral systems. Women in parliament: Beyond the numbers. Stockholm, International IDEA.

McGee, M.C. (1980). The “Ideograph”: A link between rhetoric and ideology. Quarterly Journal of Speech, 66, 1-16. doi:10.1080/00335638009383499. 
McMillan, L.R., Clifton, A.K., McGrath, D., \& Gale, W.S. (1977). Women’s language: Uncertainty or interpersonal sensitivity and emotionality? Sex Roles, 3, 545-559.

Morris, III C.E. \& Sloop, J.M. (2006). “What lips these lips have kissed”: Refiguring the politics of queer public kissing. Communication and Critical/Cultural Studies, 3, 1-26.

Norris, P. (2000). Women’s representation and electoral systems. In R. Rose (Ed.), Encyclopedia of electoral systems. Washington, D.C.: CQ Press.

Palczewski, C.H. (2005). The male Madonna and the feminine Uncle Sam: Visual argument, icons, and ideographs in 1909 anti-woman suffrage postcards. Quarterly Journal of Speech, 91, 365-394.

Pezzullo, P.C. (2003). Resisting “National Breast Cancer Awareness Month”: The rhetoric of counterpublics and their cultural performances. Quarterly Journal of Speech, 89, 345365.

Phelan, P. (1993). Unmarked: The politics of performance. New York: Routledge.

Popp, R.K. (2010). Visual culture, public space, and piety in Focus on the Family’s Citizen Magazine. Critical Studies in Media Communication, 27, 498-518.

Procházková, M. (2010, August 10). Initiatives before the house protested against missiles and government men iDNES.cz. Retrieved from iDNES.cz.

Raabe, P.H. (1998, April). Women, work, and family in the Czech Republic--and some comparisons with the West. Community, Work \& Family, 1, 51-63. doi:10.1080/13668809808414697.

Reynolds, A., Reilly, B., \& Ellis, A. (2005). Electoral system design: The new international IDEA handbook. Stockholm: International IDEA. 
Rule, W. (1994). Parliaments of, by, and for the people: Except for women? In W. Rule \& J.S. Zimmerman (Eds.), Electoral systems in comparative perspective: Their impact on women and minorities (15-30). Westport, CT: Greenwood Press.

Události, komentáře [Television broadcast]. (2010, August 10). Czech TV 24. Retrieved from http://www.ceskatelevize.cz/ivysilani/1096898594-udalostikomentare/210411000370810/.

Wolchik, S.L. (1994). Women in transition in the Czech and Slovak Republics: The first three years. Journal of Women's History, 5, 100-107. doi:10.1353/jowh.2010.0177.

Women with fake beards were not admitted to the house. (2010, August 10). ParlamentníListy.cz. Retrieved from ParlimentniListy.cz. 


\section{Notes}

${ }^{1}$ See the special issues of Argumentation and Advocacy, 33, edited by David S. Birdsell and Leo Groarke (1996).

${ }^{2}$ Forum 50\% launched its campaign in early April 2010 to make the public aware of the abysmal visibility of women on the party lists just announced for the May election. Women held approximately $25 \%$ of the list positions and were more likely to be in lower spots on the lists. The author attended the press conference of the launch, collected campaign materials, and made initial contacts with political women in attendance.

${ }^{3}$ Consider, for example, the seminal studies listed above on the ways visual imagery constitutes meaning of important social, political, and identity issues. Each is written from the perspective of U.S. culture. This study broadens that perspective to consider gender and social protest from another vantage point.

${ }^{4}$ Michael McGee (1980) explains that ideographs are not simply propositions, but they are “pregnant” with meaning, "the building blocks, of ideology” (p. 7). Terms such as equality or quota function ideographically in Czech culture, resonating with the prior order rather than suggesting progressive change.

5 The image may be viewed on Forum 50\%'s website at http://padesatprocent.cz/cz/kampane2/starsi-kampane.

${ }^{6}$ Cartoon reprinted with permission of the cartoonist.

${ }^{7}$ The cartoons may be viewed, in Czech, on the Forum 50\% website:http://padesatprocent.cz/cz/zeny-v-politice/kampan/samolepky.

8 The spots are archived at: http://padesatprocent.cz/cz/zeny-v-politice/kampan/spoty. 
${ }^{9}$ Forum 50\% archived much of the coverage here: http://padesatprocent.cz/cz/naseaktivity/kampane/kure-v-mediich-a-na-fotografiich (accessed June 18, 2012). 